\title{
Addressing Issues of Social Justice through Reflective Writing
}

\author{
JaDora Sailes \\ Bayh College of Education, Indiana State University, Terre Haute, USA \\ Email: jsailes@indstate.edu \\ Received October 29 ${ }^{\text {th }}$, 2012; revised November 30 $0^{\text {th }}$, 2012; accepted December $14^{\text {th }}, 2012$
}

\begin{abstract}
Since the 1960's there have been calls for reforms in teacher education programs to reflect the growing diversity represented in our nation's schools. One response is multicultural education courses aimed at addressing attitudes and beliefs about diversity. Such courses have received mixed reviews. Some research has reported that pre-service teacher's attitudes and beliefs were changed in a positive direction towards diversity, while others suggest that pre-service teachers leave these courses unchanged. The primary goal of this study was to determine if a stand-alone multicultural education course challenged or altered pre-service teachers' attitudes and beliefs towards cultural diversity. An analysis of reflective writings by the participants throughout the semester served as evidence of change.
\end{abstract}

Keywords: Teacher Education; Pre-Service Teachers; Multicultural Education

\section{Introduction}

As early as 1969, Smith recognized there was a need for major re-engineering of teacher education programs to prepare professionals for work in diverse learning environments. Despite this recommendation, Zeichner, (1993) reported "there is a lot of evidence that the situation hasn't changed much”. Most programs continue to place emphasis on the development of cognitive knowledge and pedagogical skills and fail to connect these elements to attitudes and beliefs which are equally important rudiments of teacher education (Gay, 2010). Attitudes and beliefs about diversity have profound influences on teacher's instructional judgments' and actions (Knopp \& Smith, 2005; Nieto, 2005; Delpit, 1995; Pajares, 1992; Smylie, 1995; Ladson-Billings, 2001). Recent reports (Geneva; Gay, 2010; Mills \& Ballatyne, 2010; Schussler, Stocksbury, \& Bercaw, 2010; Buehler, Gere, Dallavis, \& Haiviland, 2009; Villagas, 2007) support the premise that racial, ethnic, and cultural attitudes and beliefs are always present, often problematic, and profoundly significant in shaping teaching conceptions and teacher actions.

\section{Changing Attitudes and Beliefs towards Cultural Diversity}

Historically, teacher education programs have aimed to address attitudes and beliefs about diversity with add-on or piecemeal approaches (McDonald, 2005; Mills \& Ballantyne, 2010). Garmon (2004) suggested that the impact of these courses on developing positive dispositions towards diversity have yielded mixed results. Davis, et al. (2008) and others (Artitles \& McClafferty, 1998; Delany-Barmann \& Minner, 1997; Tran, Yung, \& DiLella, 1994) for example reported that students' racial attitudes and beliefs were changed in a positive direction by a course on diversity. Conversely, research by McDonald (2005), Brown (2004), Banks (2001) and others reported pre-service teachers exit these courses unchanged and often had existing stereotypical perceptions reinforced. Further, Ballantyne and Mills (2008) suggest these fragmented pro- grams do not lend themselves to the development of dispositions in pre-service teachers that are aligned with a recognitive view of social justice.

Another perspective must also be considered within the context of existing research. These studies suggest multicultural education courses may have different effects on different students. Pohan (1996) found students who bring strong biases and negative stereotypes about diverse groups to multicultural education course are less likely to develop the types of professional beliefs and behaviors most consistent with multicultural sensitivity. Similar, Garmon (2004) reported if students are not "ready" to receive instruction and experiences presented to them, even the best-designed teacher preparation programs may be ineffective in developing appropriate dispositions toward cultural diversity.

Although there is no decisive evidence which supports the impact of multicultural education courses on pre-service teachers' attitudes and beliefs toward diversity, it is profoundly evident that US schools are becoming more ethnically, racially, culturally, socially, and linguistically diverse (The Center for Public Education, 2010). In order to support the needs of these students and their families, shifts in the ideological orientations and programmatic actions of teacher education are needed. One resounding unified voice echoed in all the research is the need for the interrogation of attitudes and beliefs of prospective teachers towards diversity. This imperative is not only for white teachers but teachers of color as well. For all teachers have beliefs which have profound influences on their instructional judgments, actions, and ultimately student academic achievement (Ladson-Billings, 2006; Knopp \& Smith, 2005).

\section{Methods}

The primary goal of this study was to determine if a stand-alone multicultural education course challenged or altered pre-service teachers' attitudes and beliefs towards cultural diversity. An analysis of reflective writings by the participants throughout the semester served as evidence of change. This research effort was guided by two questions: 1) what attitudes 
and beliefs emerge from participants as they write about their perceptions on culturally diverse urban schools? 2) are those attitudes and beliefs challenged or altered during the course, and if so, what types of new awareness's emerge? In this course, cultural diversity is broadly defined, including race, class, gender, ethnicity, disability, sexual orientation, and so forth. This study aims to contribute to the knowledge base on how to prepare pre-service teachers as culturally responsive educators. Specifically, findings from this study can positively influence teacher education program design and guide the development of instructional strategies that better prepare pre-service teachers to function effectively within culturally diverse environments.

\section{Setting and Participants}

This study included 26 students in an elementary teacher education program enrolled in a multicultural education course at a large Midwestern urban public university in the United States. Most $(81 \%$,) students were female. Based on background information data supplied by the students, a substantial portion ranged in age from 18 - 30 (65\%). All self-identified themselves as white. Background information gathered from students' Cultural Autobiographies revealed their neighborhoods and schools attended were mostly rural, Christian beliefs dictated family and social life, and the student or his/her parent is the first to attend college.

\section{Description of the Course}

The conceptual framework of the course holds a social justice orientation; whereby over a 15 week period, the pre-service teachers participated in a variety of individual, small group, and whole group learning experiences (i.e. readings, discussions, videos, guest speakers, debates, and learning centers) which addressed various dimensions of cultural diversity. The learning was designed to encourage students to engage with and unpack academic literature and make sense of this in relation to their own experiences of identity, diversity, and difference (Mills \& Ballantyne, 2010). The learning experiences were focused on cultural self-awareness; awareness of different cultural worldviews; awareness of the social-construction of race; awareness of race and privilege, prejudice and discrimination in historical and contemporary societal and school contexts; knowledge of cultural patterns and culture specific knowledge; knowledge of and skill in using different communication and learning styles; knowledge and skill in using diverse classroom management strategies; ability to adapt the curriculum content to reflect cultural diversity of students; and skills to implement various pedagogies, including discourse, participation and assessment, that are culturally relevant to one's students. The selection of the learning experiences was based on research which suggested such content is necessary to develop cultural competence (Grant \& Sleeter, 2007; Banks, 2006; Hammer \& Bennett, 2001; Gay, 2000; Ladson-Billings, 1994; Bennett, 1993; Sleeter, 1992; Cross et al., 1989).

Throughout the semester, students were required to complete and submit assignments representative of the content described earlier. Below are brief descriptions of selected assignments and active learning activities which characterize content developed for the course.

Asset Based Community Assessment-The purpose of this assignment is to provide students with a research experience that will develop a comprehensive understanding of the com- munity surrounding their professional development site. The intent of this assignment is to increase awareness of the community strengths and resources that can creatively support culturally responsive teaching and high academic achievement.

Case Study - Case Studies have established themselves as an important pedagogical tool in teacher education. Cases offer the opportunity for students to construct their own understanding and be active participants in their own learning (Rand \& Shelton-Colangelo, 1999). Your Task: Please read the Case Study "Low Expectations". Next, Place yourself in the role of an educational consultant. Creatively restructure the classroom described in the case study by differentiating instructional and classroom practices which meet the needs of a mixed-ability group. During this process, group members should consider learning styles and conditions which promote high academic performance, motivational profiles, assessment/evaluation, classroom environment, varying cultures represented in the classroom, etc.

Classroom Mosaic - "In any interaction, we bring various ideas, cultural orientations, physical abilities and disabilities, as well as perspectives based on age, race, gender, religion ethnicity, sexual orientation, employment experience, educational experience, and more. For society to deal with this intricate web of characteristics, our educational programs must prepare people to embrace the world's diversity in all of its dimensions. We must create a society in which differences are celebrated and not allowed to become the subject of tension or discriminatory behavior. We must prepare people for building on their individuality in a context where the many aspects of personhood are valued, intrinsically, as contributions to a fascinating and beautiful social mosaic” (Gerald Bepko, 2000). Your Task: Using the card stock paper, markers, crayons, scrap paper, scissors, glue, etc. provided create an individual mosaic which represents your personhood. Consider your values, personal/philosophical beliefs and socio and cultural influences that have contributed to who you are today. Use your imagination and be creative. Afterwards, write a personal reflection which deeply examines the illustrations depicted in your individual mosaic.

Cultural Autobiography-The purpose of this assignment is to help students gain a deeper understanding of how he/she came to develop their values and beliefs and identify through significant life experiences. These include family and community values, and attitudes about those who were "different" from you (disability, religion, language, race, gender, sexual orientation, social economic status, etc.)? Further, students will reflect upon the implications of their cultural experiences in relationship to their work as a future educator.

Personal Philosophy and Action Plan-This end of the semester culminating assignment invites each student to reflect and synthesize what was learned in a way that is personally meaningful and demonstrates learning. This process will require students to examine their strengths and challenges relative to culturally responsive and inclusive practices which will result in an action plan detailing next steps for personal and professional development towards social justice.

A two hour one day a week field experience which met for six consecutive weeks in conjunction with the classroom learning experience was another component of the course. The pre-service teachers were participant observers in an urban school. The racial demographics of the elementary school was approximately 1/3 African American, 1/3 Latino, and 1/3 white. 
Pre-service teachers worked with small groups and/or individual students under the guidance of a mentor teacher. The purpose of the field experience was to provide experiential learning opportunities about urban education, urban communities, and to serve as a platform for reflection on issues regarding equity, diversity, multicultural education, inclusion, special education, child development and learning theories. Further, it was desired that during field experience, pre-service teachers witnessed how mentor teachers responded to the needs of their students representing various cultures by implementing culturally relevant pedagogy which honors, respects, and values cultural differences (Klotz, 2006).

\section{Data Sources}

Reflective writings were the primary sources of data collection for this study. They were instrumental in identifying existing and emerging attitudes and beliefs about cultural diversity and if and how these beliefs were challenged or altered. Reflective practice was a critical component of the multicultural education course. It is one of the guiding principles mandated by the Interstate New Teacher Assessment and Support Consortium (INTASC). The teacher education program represented in this study is governed by this consortium of State agencies and national education organizations which oversees the professional development of teachers. The reflective papers required pre-service teachers to provide a description of an event (e.g. article, reading, classroom activity, field experience, etc.) and its implications for effective teaching. Through this process, pre-service teachers examined their feelings and reactions, thoughts and assumptions, alternative perspectives of a described event and the applications of personal discoveries as a future educator. Ideally, this reflective process will become an important component of their future teaching. As Ladson-Billings (2006) pointed out, "culturally relevant teachers think deeply about what and how they teach".

\section{Procedure}

Pre-service teachers were introduced to the research study on the first day of class. The instructor of this class also served as the principal investigator of the study. The pre-service teachers were informed participation was voluntary and explained participation or non-participation had no bearing on the outcome of final grades. Further, reflective papers were non-graded assignments. This decision was intentional to minimize "socially desirable" responses. Although it cannot be ruled out, the possibility that such responses were represented in the data.

This study did not focus on student's attitudes and beliefs about cultural diversity prior to their enrollment in the course. Therefore, the researcher is drawing on students' perceptions of whether and how their attitudes and beliefs shifted as a result of the course. This decision was not regarded as a weakness of the study; for students may not have considered their attitudes beliefs towards diversity prior to their involvement in the course (Mills \& Ballantyne, 2010).

\section{Data Analysis}

The constant comparative method was used to examine emerging themes from reflective writings. In this process, concrete instances of data were linked together into more general categories and either accumulated for evidence and ideas, or was used for clarification and correction of previously developed themes (Guba \& Lincoln, 1994; Glaser \& Strauss, 1967). Further, to ensure the credibility of findings, pre-service teachers were debriefed throughout the semester to confirm or correct data interpretations (Marshall \& Rossman, 2006). It must also be noted that reflective papers did not contain the same amount of reflection across participants; however this source offered useful data for triangulating evidence or discrepancies in the interpretation of data (Campbell \& Lott, 2010)

\section{Key Findings}

The analysis of reflective writing assignments suggested pre-service teachers' attitudes and beliefs towards culturally diverse urban schools had been altered while enrolled in a multicultural education course. At the beginning of the semester, reflective writings indicated their beliefs were situated from a deficit perspective whereby racially diverse students in urban schools were viewed as underachievers, poorly prepared, and lagging behind their white classmates (Milner, 2011). The following selected commentary from reflective writings provided insights into their initial attitudes and beliefs and how they had been altered over the course of the semester.

\section{Changes in Perceptions}

"The students were far from what I expected. In fact, instead of being the disrespectful wild kids I thought they would be, they were the best behaved class of students I have ever encountered. They also treated one another and authority figures with tremendous respect."

"My perceptions about urban schools have changed. I know that at first I was scared to go into an urban school. I thought that the children would not respond to me and see me as a threat."

"Once in these schools, I was thrilled to realize that we shared many similarities, differences, likes, dislikes, hobbies! My previous fears and assumptions' were put to rest after I understood that urban schools were in need of the same committed, enthusiastic, and passionate teachers that every other school needs."

"After interacting with those at XXXX Elementary School, my perceptions have changed tremendously. Just from the one day of observation, so far I see students in Miss XXXX class are just like students in every class I have ever been in or observed."

This commentary revealed the pre-service teachers who attended mostly rural schools prior to college had adopted a positive position toward cultural diversity in urban schools. Further, analysis of the reflective writings suggested this new awareness may have heightened their consideration of teaching in an urban setting. These writings asserted.

\section{Changes in Attitudes towards Teaching in an Urban School}

"I am now seriously considering teaching in an urban setting. I have fallen in love with the children; plus it is refreshing to be around people who are different than me. It reminds me what a big world we live in and all of the things I still have to learn."

"I see myself now loving urban schools more than any other district because I feel I can make the most impact there."

"... I now think it would be a great experience to work in an urban school." 
"Knowing what I know now I would be more than willing to work in an urban setting."

"I see myself now as not being apprehensive about one day teaching in an urban environment."

The altered perceptions described earlier coincided with reflective writings composed during the third week of field experience. Field experience was implemented in week six of the fifteen week semester.

In order to corroborate the researchers' initial results of the study, participants were debriefed on the findings. During this process, the pre-service teachers indicated that the field experience and support group discussions were most critical in facilitating changes in attitudes and beliefs towards culturally diverse urban schools. A support group in this case is defined as individuals who encourage a person's growth through listening to him or her, helping him or her process and make sense of relevant information and/or experiences, questioning or challenging the person's words/or actions as a means of pushing him or her to think more deeply, and sometimes expanding the person's knowledge or awareness by providing additional information when needed (Garmon, 2004, Fry \& McKinney, 1997). Throughout the semester, time was allocated each class meeting to discuss readings, group activities, field experiences and other learning experiences.

Surprisingly, in a subsequent debriefing held before the last class meeting, the researcher discovered that some students who are all white may not have fully grasped how one's cultural identity influences access or denial to opportunities. This was especially striking, given the length and depth of discussions and course content covered on race and privilege. This inclination was supported by a spirited exchange on "white privilege" between two students. One student commented, “... everyone has the same equal opportunity for education, as long as they have the desire and motivation to learn". The other student's response admonished this position. Her thoughts were later captured in a reflective paper. She wrote, “I don't typically speak my mind the way I did the other day in class. I wouldn't want to upset anyone, but when XXX mentioned that everyone has the same opportunities in America, I knew he was mistaken. The only way that I felt I could get my point across was to ask him to think about if he would want to be an African American. I said that I knew I wouldn't. That may seem like a bold statement but I kept thinking about what I had just read. The article is entitled White Privilege: Unpacking the Invisible Knapsack by Peggy McIntosh. She talks about how easy it is to be a white person, the things that we don't have to think about. A couple of statements that stood out to me were; that I could move just about anywhere and be sure that white people would live there too and that I could be sure that when I turned on the television that the white race would be represented.

I grew up at a time when it was extremely unusual to see anyone other than the white man in charge. Everywhere I looked my race was represented; the presidents, the history books, the television shows, the news anchors, the magazines, the billionaires, the senators, the teachers, the doctors, the toys, the actors, and I could go on and on. I wonder how I would feel if my skin would have been a different color. What effect would that have had on me and how would my attitude be different?

I know things have changed and will continue to change so that we will see more people of color represented in a positive light. I still don't think I would want to be anything other than white because life is hard enough. We are always trying to prove ourselves and why would I want the color of my skin to be one more thing that people judged me on?"

Although research findings supported by debriefings indicated that attitudes and beliefs had been altered in a positive manner towards culturally diverse urban schools, the formentioned exchange between the two students might imply some pre-service teachers enrolled in the course were unable to comprehend or simply rejected the notion that sociocultural structures hinder access to resources essential to academic achievement (Howard, 2008; Conchas, 2006; Ladson-Billings, 2001; Nieto, 2005); while others in the course may have engendered a growing awareness of social inequities as they begin to construct a nascent understanding of their privileged social position (Gosselin, 2009).

\section{Discussion and Recommendations}

Many researchers have explored ways in which teacher education programs can foster positive change in attitudes and beliefs toward cultural diversity, specifically through fieldbased experiences and university coursework (Castro, 2010; Bell, Horn, \& Roxas, 2007; Conway, Browning, \& PurdumCassidy, 2007; Causey, Thomas, \& Armento, 2000). The results of this study have shown urban field experiences combined with coursework and guided discussions will have positive effects on pre-service teacher's attitudes and beliefs towards culturally diverse urban schools. Given the ever changing demographics in all schools, it is critical that teacher education programs give special consideration on ways to expose pre-service teachers to field experiences in diverse classroom settings, where pre-service teachers can have numerous opportunities to reflect upon and discuss cultural perceptions which contribute to an inclusive, tolerant, and expanded knowledge base (Terrill \& Mark, 2000) which undergirds the success of each and every child. However, these recommended practices must move beyond a single course. A one-time only multicultural education course may not lend itself to the development of dispositions in pre-service teachers which are aligned with a recognitive view of social justice (Allantyne \& Mills, 2008). Therefore, it is critical that multicultural education principles and ideas be introduced and developed across an entire preparation program, not just added as one component (Chisholm, 1994).

The results of this study must be considered in the context of its limitations. First, the research consisted of only 26 students. Therefore, research findings have limited generalizations. Second, the researcher acknowledges that students' entering attitudes and beliefs serve as filters for what they learn. This study did not examine experiential cultural factors which may have influenced the research participants' dispositions towards cultural differences prior to entering the course. As such, tentative assertions can only be made about the degree of influence experiential experiences incorporated in the multicultural education course had on the development of positive attitudes and beliefs towards cultural diversity.

Similar to Garmon's research (2004), this study revealed that participation in a provision of early, ample, and carefully supported fieldwork in urban schools and support group experiences (i.e. class discussions) contributes to the development of attitudes and beliefs which support multicultural awareness and sensitivity. Hopefully, these attitudinal changes will be reflected in pedagogical practices which support equity in schools 
and ultimately, high academic achievement for all students (Grant \& Sleeter, 2007; Banks, 2006; Garmon, 2004; Gay, 2000; Ladson-Billings, 1992,). Though not conclusive, this research also suggested field experiences in culturally diverse settings affect the career expectations of pre-service teachers by heightening their consideration of teaching in an urban setting. Again, this finding speaks to the importance of establishing and maintaining relationships between urban schools and teacher education programs. By doing so, future educators will be better positioned to create culturally responsive and "socially just" classrooms which are evidenced by rigorous subject matter, differentiated pedagogy, an ethic of care, equitable inclusion, and social action pedagogy whereby teaching encourages the development of democratic citizens who understand and engage social issues (Kose, 2007; Banks, 2006). However, in order to promote these highly desirable pedagogical practices, positive attitudes and beliefs towards diversity must be deemed as an important outcome of teacher education programs. Therefore, it is imperative that teacher education programs develop student assessment plans which incorporate rubrics that define what culturally responsive practice is and include ways to measure students' progress toward those goals over the course of the program (Dee \& Henkin, 2002). Otherwise, pre-service teachers may not view multicultural education as a vital aspect of personal and professional development (Groulx, 2001; Chisholm, 1994; Reiff \& Cannella, 1992).

\section{REFERENCES}

Artiles, A. J., \& McClafferty, K. (1998). Learning to teach culturally diverse learners: Charting change in preservice teachers' thinking about effective teaching. Elementary School Journal, 98, 189-220. doi:10.1086/461891

Ballantyne, J., \& Mills, C. (2008). Promoting socially just and inclusive music teacher education: Exploring perceptions of early-career teachers. Research Studies in Music Education, 30, 77-91. doi:10.1177/1321103X08089891

Banks, J. (2006). Multicultural education: Issues and perspectives (6th ed.). Hoboken, NJ: John Wiley \& Sons, Inc.

Banks, J. (2001). Cultural diversity and education: Foundations, curriculum, and teaching (4th ed.). Boston, MA: Allyn \& Bacon.

Bell, C. A., Horn, B. R., \& Roxas, K. C. (2007). We know it’s service, but what are learning preservice teachers' understandings of diversity. Equity and Excellence in Education, 40, 123-133. doi:10.1080/10665680701218467

Bennett, M. J. (1993). Towards ethnocentricism: A developmental model of intercultural sensitivity. In R. M. Paige (Ed.), Education for the intercultural Experience (2nd ed.). Yarmouth, ME: Intercultural Press.

Buehler, J., Gere, A. R., Dallavis, C., \& Haviland V. S. (2009). Normalizing the fraughtness. How emotion, race, and school context complicate cultural competence. Journal of Teacher Education, 60, 408-418. doi:10.1177/0022487109339905

Campbell, T., \& Lott, K. (2010). Triad dynamics: Investigating social forces, roles, and storylines. Teacher Education, 21, 349-366. doi:10.1080/10476210903518396

Castor, A. (2010). Themes in the research on preservice teachers' views of cultural diversity: Implications for researching millennial preservice teachers. Educational Researcher, 39, 198-210. doi:10.3102/0013189X10363819

Causey, V. E., Thomas, C. D., \& Armento, B. J. (2000). Cultural diversity is basically a foreign term to me: The challenges of diversity for preservice teacher education. Teaching and Teacher Education, 16, 33-45. doi:10.1016/S0742-051X(99)00039-6

Chisholm, I. M. (1994). Preparing teachers for multicultural classrooms. Journal of Educational Issues of Language Minority Students, 14,
43-68.

Conchas, G. (2006). Color of success: Race and achievement in urban schools. New York: Houghton Mifflin Co.

Conway, B., Browning, L., \& Purdum-Cassidy, B. (2007). Teacher candidates' perceptions of urban schools. Results of a 4-year study. Action in Teacher Education, 28, 20-321. doi:10.1080/01626620.2007.10463436

Cross, T. L., Bazron, B. J., Dennis, K. W., \& Issacs, M. R., (1989). Toward a culturally competent System of care. Washington DC: Georgetown University Development Center.

Davis, R., Ramahlo, T. Beyerback, B., \& London, A. (2008). A culturally relevant teaching course: Reflecting preservice teachers' thinking. Teaching Education, 19, 223-234. doi:10.1080/10476210802250265

Dee, J., \& Henkin, A. (2002). Assessing dispositions toward cultural diversity among preservice teachers. Urban Education, 37, 22-40. doi:10.1177/0042085902371003

Delany-Barmann, G., \& Minner, S. (1997). Development and implementation of a program of study to prepare teachers for diversity. Equity and Excellence in Education, 30, 78-85. doi:10.1080/1066568970300209

Delpit, L. (1995). Other people’s children. New York: Houghton Mifflin Co.

Fry, P., \& McKinney, L. (1997). A qualitative study of preservice teachers' early field experiences in an urban, culturally different school. Urban Education, 32, 184-198. doi:10.1177/0042085997032002002

Garmon, M. A. (2004). Changing preservice teachers' attitudes/beliefs about diversity: What are the critical factors? Journal of Teacher Education, 55, 201-213. doi:10.1177/0022487104263080

Gay, G. (2010). Acting on teacher education for cultural diversity. Journal of Teacher Education, 61, 143-152.

Glaser, B., \& Strauss, A. (1967). The discovery of grounded theory. Chicago, IL: Aldine.

Gosselin, C. (2009). Emerging awareness: Preservice teachers reflections. Denver, CO: National Association for Multicultural Education.

Grant, C., \& Sleeter, C. (2007). Doing multicultural education for achievement and equity. New York: Routledge.

Groulx, J. (2001). Changing preservice teacher perceptions of minority schools. Urban Education, 36, 60-92. doi:10.1177/0042085901361005

Guba, E., \& Lincoln, Y. (1994). Competing paradigms in qualitative research. In N. Denzin, \& Y. Lincoln (Eds.), Handbook of qualitative research (pp. 105-117). Thousand Oaks, CA: Sage.

Hammer, M. R., \& Bennett, M. J. (2001). Intercultural development inventory. Portland, OR: Intercultural Communication Institute.

Howard, A. (2008). Learning privilege. New York, NY: Routlege.

Klotz, M. B. (2006). Culturally competent schools: Guidelines for secondary school principals. National Association of School Psychologist Journal, 6, 11-14.

Knopp, T. Y., \& Smith, R. L. (2005). A brief historical context for dispositions in teacher education. In R. L. Smith, D. Skarbek, \& J. Hurst (Eds.), The passion of teaching: Dispositions in the schools (pp. 1-13). Lanham, MD: Scarecrow Education.

Kose, B. (2007). One principal's influence on sustained, systemic, and differentiated professional development for social justice. Middle School Journal, 39, 34-42.

Ladson-Billings, G. (2006). Yes, but how do we do it? In J. Landsman, \& C. Lewis (Eds.) White teachers/diverse classrooms: A guide to building inclusive schools, promoting high expectations, and eliminating racism. Sterling, VA: Stylus.

Ladson-Billings, G. (2001). Crossing over to Canaan: The journey of new teachers in diverse classrooms. San Francisco, CA: Jossey-Bass.

Ladson-Billings, G. (1992). Culturally relevant teaching: The key to making multicultural education work. In C. A. Grant (Ed.), Research and multicultural education: From margins to the mainstream (pp. 107-121). Washington DC: Falmer Press.

Marshall, C., \& Rossman, G. (2006). Designing qualitative research, (4th ed.). Thousand Oaks, CA: Sage Publications

Mills, C. \& Ballantyne, J. (2010). Preservice teachers' dispositions 
towards diversity: Arguing for a developmental hierarchy of change. Teaching and Teacher Education, 26, 447-454.

doi:10.1016/j.tate.2009.05.012

Milner, R. (2011). Start where you are, but don't stay there. Cambride, MA: Harvard Education Press.

Nieto, S. (2005). Afirming diversity. Boston, MA: Pearson Education.

Pajares, M. F. (1992). Teachers' beliefs and educational research: Cleaning up a messy construct. Review of Educational Research, 62, 307-332. doi:10.2307/1170741

Pohan, C. A. (1996). Preservice teachers' beliefs about diversity: Uncovering factors leading to multicultural responsiveness. Equity and Excellence in Education, 29, 261-275.

doi:10.1080/1066568960290310

Reiff, J. C., \& Cannella, G. (1992). Multicultural beliefs and conceptual level of early childhood preservice teachers. The Annual Meeting of the Association of Teacher Educators, Orlando, FL: The Association Of Teacher Educators.

Schussler, D., Stooksbury, L. M., \& Bercaw, L. A. (2010). Understanding teacher candidate dispositions: Reflecting to build selfawareness. Journal of Teacher Education, 61, 350-363. doi:10.1177/0022487110371377

Sleeter, C. E. (1992). Keepers of the American dream: A study of staff development and Multicultural education. London and Washington DC: Falmer Press.

Smith, B. (1969). Teachers for the real world. Washington DC: American Association of Colleges for Teacher Education.
Smylie, M. A. (1995). Teacher learning in the work place: Implications for school reform. In T. R. Guskey, \& M. Huberman (Eds.), Professional development in education: New paradigms and practices (pp. 92-113). New York: Teachers College Press.

Terrill, M. \& Mark, D. (2000). Preservice teachers' expectations for schools with children of color and second-language learners. Journal of Teacher Education, 51, 149-155. doi:10.1177/002248710005100209

The Center for Public Education (2010). The United States of education: The changing demographics of the United States and their schools. URL (last checked 17 March 2012).

http://www.centerforpubliceducation.org/Main-Menu/Staffingstudent s/Chaing-Demographics-At-a-glance-/The-United-States-of-educatio n-The-changing-demographics-of-the-United-States-and-their-school s.html

Tran, M. T., Young, R. L., \& Di Lella, J. D. (1994). Multicultural education courses and the student Teacher: Eliminating stereotypical attitudes inour ethnically diverse classroom. Journal of Teacher Education, 45, 183-189. doi:10.1177/0022487194045003004

Villegas, A. M. (2007). Dispositions in teacher education: A look at social justice. Journal of Teacher Education, 58, 370-380. doi:10.1177/0022487107308419

Zeichner, K. (1993). Educating teachers for cultural diversity: NCRTL Special Report. East Lansing, MI: Michigan State University, National Center for Research on TeacherLearning. 